\title{
Pengenalan Nilai Budaya dengan Menggunakan Cerita Rakyat untuk Meningkatkan Literasi Bahasa Inggris di Taman Bacaan Masyarakat (TBM), Ciputat
}

\author{
Anita Sari $^{1}$, Erni Susanti Nainggolan ${ }^{2}$, May Triranto Maharini ${ }^{3}$ \\ Sarita Merilia $^{4}$, Wirharyati ${ }^{5}$ \\ Universitas Pamulang \\ Korespondensi: dosen01170@unpam.ac.id ${ }^{1}$, dosen01683@unpam.ac.id², \\ dosen01169@unpam.ac.id ${ }^{3}$, dosen01710@unpam.ac.id ${ }^{4}$, dosen00170@unpam.ac.id ${ }^{5}$
}

\begin{abstract}
Folk culture is defined as a set of features, which along with the elements comprising national culture, determine the identity of people. A folktale is one of Indonesian national heritage consisted of various cultures which have to be introduced by elementary students. This article describes "Malin Kundang" folktale as the way to improve children's English literacy. The aims of this project are to maximize reading activity and to improve children's English literacy which contains cultural values through a folktale story book. The object of this project is the students of Taman Baca Masyarakat (TBM) Kolong Jembatan, Ciputat. The method used in this Community Service is communicative approach through role playing and storytelling. The roleplaying utilizes puppets as the aid. The puppets represent the roles of the characters in Malin Kondang story. The roleplay is done using storytelling technique. The result of this activity is the increased of children's English literacy and knowledge about cultural values that they can apply into their daily life.
\end{abstract}

Keywords: communicative, cultural value, English, folktale story book, literacy

\begin{abstract}
Abstrak
Budaya rakyat di definisikan sebagai satu kesatuan yang terkandung dalam budaya nasional yang menjadi identitas seseorang. Cerita rakyat adalah salah satu warisan kebudayaan nasional yang menjadi kehormatan bangsa dengan budaya yang beraneka ragam yang harus diperkenalkan kepada siswa sejak sekolah dasar. Artikel ini mendeskripsikan cerita rakyat "Malin Kundang" sebagai cara untuk meningkatkan literasi anak-anak dalam berbahasa Inggris. Kegiatan Pengabdian Kepada Masyarakat dengan tema "Introducing Cultural Values By Using Traditional Folktale To Improve English Literacy At Taman Baca Masyarakat (TBM) Kolong, Ciputat Tangerang Selatan" bertujuan untuk memaksimalkan kegiatan membaca yang lebih menarik dan menumbuh kembangkan literasi dengan menggunakan buku cerita daerah. Anak - anak binaan di Taman Baca Masyarakat (TBM) yang juga merupakan peserta Pengabdian Kepada Masyarakat (PKM) ini dapat menumbuh kembangkan literasi mereka yang mengandung nilai - nilai budaya pada" buku cerita daerah. Metode yang digunakan pada PKM ini berupa pendekatan komunikatif melalui bermain peran (roleplaying) dengan menggunakan puppet dan bercerita (storytelling). Roleplaying yang dilakukan menggunakan boneka yang merepresentasikan para karakter dalam cerita Malin Kundang dan diceritakan dengan teknik storytelling. Kemudian hasil pengabdian masyarakat yang diperoleh adalah peningkatan kesadaran akan pentingnya membaca serta memperkaya pengetahuan bagi anak - anak akan nilai - nilai budaya daerah yang dapat diaplikasikan dalam keseharian mereka.
\end{abstract}

Kata kunci: bahasa Inggris, cerita daerah, literasi, komunikatif, nilai budaya 


\section{A. Pendahuluan}

Pendidikan adalah salah satu sektor penting agar sebuah negara dapat dikatakan maju dan berkembang. Tingginya pendidikan yang dimiliki oleh sumber daya manusia dalam suatu negara tentu akan menjamin pengelolaan yang baik pula terhadap sumber daya yang ada dalam negara. Oleh sebab itu, Indonesia menempatkan pendidikan sebagai sesuatu yang penting dan utama. Budaya literasi dini penting untuk dikembangkan guna membentuk perilaku dan kecakapan hidup yang diharapkan di masyarakat. Secara sederhana, literasi diartikan sebagai sebuah kemampuan membaca dan menulis. Sulhan (2006: 91) menyatakan bahwa "kemampuan literasi (mendengar, berbicara, membaca, dan menulis) merupakan kemampuan dasar yang perlu dikuasai siswa dalam meraih cita-citanya". Salah satu hal yang paling ditekankan dalam budaya literasi adalah peningkatkan kemampuan membaca siswa.

Budaya literasi tentunya tidak hanya diterapkan di sekolah, namun bisa untuk segala lapisan masyarakat yang berada di berbagai tempat. Menyikapi permasalah literasi tersebut, Tim Pengabdian Kepada Masyarakat (PKM), Program Studi Sastra Inggris, Universitas Pamulang, yang terdiri atas lima dosen Sastra Inggris dan dua belas mahasiswa, tergerak hati untuk kali ini melaksanakan program pelatihan literasi, dengan judul "Pengenalan Nilai Budaya dengan Menggunakan Cerita Rakyat Untuk Meningkatkan Literasi Bahasa Inggris di Taman Bacaan Masyarakat (TBM), Ciputat." Tempat yang di tuju adalah Taman Baca Masyarakat atau TBM Kolong yang berada di Jalan Dewi Sartika, Ciputat-Tangerang Selatan. Taman Baca Masyarakat Kolong adalah taman baca yang didirikan di kolong flyover Ciputat. Tempat tersebut berdiri pada tahun 2016, sudah sekitar empat tahun keberadaannya. Adapun tujuannya yaitu untuk menambah minat membaca pada anak-anak dan mengisi kegiatan positif untuk mereka. Kegiatan ini menawarkan solusisolusi untuk permasalahan tersebut, yaitu berupa peningkatan motivasi dan minat baca di kalangan generasi muda, melalui kegiatan mendongeng yang disertai dengan beragam kegiatan edukatif kreatif lainnya, serta penyediakan media kegiatan yang dapat digunakan demi tercapainya tujuan kegiatan ini. Kegiatan PKM ini adalah untuk mengupayakan peningkatan minat baca di kalangan anakanak usia 4 sampai dengan 6 tahun yang distimulasi melalui pembacaan dongeng yang merupakan bentuk tradisi budaya lisan. Permasalahan yang teridentifikasi adalah minat baca yang sangat kurang karena keterbatasan finansial dan fasilitas yang ada di TBM kolong.

Para relawan berpartipasi dan berkontribusi dalam kegiatan yang diselenggarakan di Taman Baca Masyarakat Kolong. Tim Pengabdian Kepada Masyarakat Universitas Pamulang memberikan pelatihan dan pembelajaran seputar literasi kepada anak-anak sekitar Kolong Ciputat. Tim Pengabdian Kepada Masyarakat memberikan pelatihan dan pembelajaran literasi lebih menarik lagi, sehingga anak-anak sekitar Kolong dapat merasakan suasana yang baru dalam berliterasi. Dalam mendukung Program Literasi Dasar, Tim Pengabdian Kepada Masyarakat bekerjasama dengan pihak Taman Baca 
Masyarakat untuk bisa lebih membuat anak-anak sekitar Kolong Ciputat agar bisa mencintai budaya membaca dan terampil dalam menulis. Tim Pengabdian Kepada Masyarakat mengangkat sebuah cerita rakyat Indonesia dalam bahasa Inggris. Pengembangan cara membaca dan mengeksplorasi cerita yang didukung dengan intonasi dan gaya bercerita yang menarik sehingga dapat membuat anak-anak di Taman Baca Masyarakat Kolong antusias dan produktif dalam membaca hingga menulis kelak. Cerita yang diangkat tentunya tanpa menghilangkan nilai budaya atau nilai karakter yang terkandung di dalam cerita tersebut. Hal tersebut memegang peranan yang penting dalam pengembangan literasi tentunya.

Harvery (2016) mengungkapkan cerita anak adalah karangan yang menuturkan perbuatan, pengalaman, kejadian yang ditujukan untuk anak yang muatan ceritanya sederhana, kompleks dan komunikatif serta mengandung nilai moral bagi anak. Menurut Kamus Besar Bahasa Indonesia (KBBI) cerita anak adalah 1) tuturan yang membentangkan bagaimana terjadinya suatu hal (peristiwa, kejadian, dsb) 2) karangan yang menuturkan perbuatan, pengalaman atau penderitaan orang; kejadian dsb (baik yang sungguh-sungguh terjadi maupun yang hanya rekaan belaka); 3) lakon yang diwujudkan dalam gambar hidup (sandiwara, wayan, dll). Sarumpaet (2003: 108) berpendapat bahwa cerita yang ditulis, berbicara mengenai kehidupan anak dan sekeliling hanya dapat dinikmati oleh anak dengan bantuan dan pengarahan orang dewasa. Jenis cerita anak dapat dikelompokan menjadi cerita jenaka, dongeng, fabel, legenda, dan mite atau mitos. Jenis cerita yang cocok untuk anak usia SD diantaranya: (1) Dongeng adalah cerita yang didasari atas anganangan atau hayalan. Dongeng merupakan suatu cerita yang hidup dikalangan rakyat yang disajikan dengan cara bertutur lisan. (2) Cerita rakyat merupakan cerita yang alurnya mirip dengan legenda, yang mengungkap penyelesaian masalah secara baik dan adil. (3) Puisi merupakan nyanyian tanpa notasi. Puisi merupakan bentuk karya satra yang paling imajinatif dan mendalam mengenai alam sekitar, cinta, kasih sayang, perjuangan, dll. (4) Fabel adalah cerita yang menampilkan hewan-hewan sebagai tokohtokohnya. Fabel adalah cerita yang digunakan untuk pendidikan moral. (5) Legenda adalah cerita yang berasal dari zaman dahulu. Cerita legenda bertalian dengan sejarah yang sesuai dengan kenyataan yang ada pada alam. (6) Mite Atau Mitos merupakan cerita yang berkaitan dengan kepercayaan kuno, menyangkut kehidupan dewa-dewa atau kehidupan makhluk halus.

Sarumpaet (2003) menambahkan bahwa Gerakan budaya literasi sekolah hendaknya menekankan prinsip-prinsip sebagai berikut: (1) Perkembangan literasi berjalan sesuai tahap perkembangan anak. (2) Bersifat berimbang yang menerapkan program literasi karena tiap siswa memiliki kebutuhan yang berbeda. Oleh karena itu, strategi membaca dan jenis teks yang dibaca perlu divariasikan dan disesuaikan dengan jenjang pendidikan. (3) Terintegrasi dengan kurikulum dan pembelajaran literasi di sekolah adalah tanggung jawab semua guru di semua mata pelajaran, sebab pembelajaran apapun membutuhkan bahasa, terutama membaca dan menulis. (4) Kegiatan membaca dan menulis dilakukan kapan pun. (5) Kegiatan literasi mengembangkan budaya lisan kelas berbasis literasi yang 
kuat. (6) Mampu menjadi garis depan dalam pengembangan budaya literasi untuk menciptakan budaya literasi yang positif di sekolah.

Apa itu literasi? Dapat dikatakan bahwa literasi berhubungan dengan kemampuan seseorang dalam membaca, menulis, berbicara, dan berhitung. Lebih terperinci lagi, literasi sebenarnya lebih menekankan pada kebiasaan membaca dan menulis. United Nations of Educational, Scientific, and Cultural Organization atau UNESCO mendefinisikan literasi adalah seperangkat keterampilan yang nyata, khususnya keterampilan kognitif dalam membaca dan menulis yang terlepas dari konteks di mana keterampilan yang dimaksud diperoleh, dari siapa keterampilan tersebut diperoleh dan bagaimana cara memperolehnya. UNESCO menekankan pada kemampuan kognitif dan nilai-nilai budaya. Pendapat UNESCO diperkuat oleh Harvey J.Graff (2006), berkata bahwa literasi adalah suatu kemampuan dalam diri seseorang untuk membaca dan menulis. Sedangkan menurut Kern, literasi itu mengandung tujuh prinsip pendidikan diantaranya literasi melibatkan interprestasi, kolaborasi, konvensi, pengetahuan kultural, pemecahan masalah, refleksi diri, dan penggunaan bahasa. Kemampuan anak-anak atau orang dewasa dalam memecahkan masalah ataupun penggunaan bahasa masih kurang, ternyata hal tersebut bisa disebabkan oleh minusnya dalam membaca buku.

Meskipun penggunaan literasi sudah sangat jamak, namun tetaplah istilah tersebut merujuk kepada kemampuan membaca dan menulis. Berikut ini adalah beberapa jenis literasi yaitu:

1. Literasi Media adalah kemampuan untuk memahami, menganalisa, dan mendekonstruksi pencitraan media. Literasi ini bertujuan untuk membuat pemirsa sebagai konsumen media menjadi sadar tentang cara media dikonstruksi dan diakses.

2. Literasi Digital Inklusif adalah bagian dari program Hackathon Merdeka yang spesifik mengajarkan literasi digital kepada anak-anak Sekolah Menengah, dimana diajarkan game development.

3. Literasi Informasi merupakan kemampuan untuk menemukan dan menggunakan informasi dalam kehidupan.

4. Literasi Saintifik adalah kemampuan menerapkan penguasaan sains dalam menyelesaikan masalah yang dihadapi. Literasi saintifik dipilih sebagai tujuan utama pendidikan sains.

5. Literasi teknologi adalah kemampuan dalam mengetahui dan memahami hal-hal yang berhubungan dengan teknologi.

6. Literasi Dasar adalah kemampuan dasar dalam membaca, menulis mendengarkan dan berhitung. Tujuannya yaitu mengoptimalkan kemampuan membaca dan menulis.

7. Literasi Visual adalah pemahaman yang lebih dalam menginterpretasi dan memberimakna dari suatu informasi yang befrbentuk gambar atau visual.

Mengapa literasi penting? Pertanyaan tersebut pastinya mempunyai jawaban yang signifikan, sehingga Pemerintah Indonesia menggalakannya. Hernowo (2005) dalam bukunya "Mengikat Makna" menyebut bahwa menulis 
dapat membuat pikiran seseorang lebih tertata, membuat seseorang bisa merumuskan keadaan diri, mengikat dan mengonstruksi gagasan, mengefektifkan atau membuat seseorang memiliki sugesti positif, membuat seseorang semakin pandai memahami sesuatu (menajamkan pemahaman), meningkatkan daya ingat, lebih mengenali diri sendiri, mengalirkan diri, membuang kotoran diri, merekam momen mengesankan yang dialami, meninggalkan jejak pikiran yang sangat jelas, memfasihkan komunikasi, memperbanyak kosa-kata, membantu bekerjanya imajinasi, dan menyebarkan pengetahuan. Jelaslah bahwa literasi bermanfaat untuk mengoptimalkan kinerja otak kita karena sering digunakan untuk kegiatan membaca dan menulis, mengembangkan kemampuan verbal, menambah kosa kata, melatih kemampuan berfikir dan menganalisa. Selain itu wawasan kita semakin bertambah seiring dengan informasi yang melesat begitu cepatnya. Oleh sebab itu, sebaiknya literasi dikembangkan bahkan menjadi kebiasaan anak-anak sejak usia dini.

Sesuai dengan uraian mengenai literasi yang dikemukakan oleh para ahli di atas, maka penting untuk masyarakat yang dapat dimulai dari lingkup seperti TBM Kolong untuk mengedepankan literasi sebagai hal yang perlu ditingkatkan. Karena itu, meskipun terdapat keterbatasan dari keadaan atau situasi yang ada dalam lingkungan TBM Kolong, Tim Pengabdian Kepada Masyarakat berupaya untuk mewujudkan kegiatan peningkatan literasi ini dengan beberapa langkah dan solusi. Adapun solusi dari permasalahan yang dihadapi adalah sebagai berikut:

\section{Pemilihan Buku yang Tepat}

Tim Pengabdian Kepada Masyarakat menentukan topik buku yang dapat dieksplore secara pendekatan budaya yaitu cerita rakyat Malin Kundang. Cerita daerah tersebut dipilih untuk meningkatkan minat dan kemampuan literasi pada anak yang disisipkan pula nilai-nilai unsur budaya dalam buku yang akan dibaca oleh anak-anak tersebut.

2. Sharing

Setelah ditentukan satu jenis buku yang dapat mengenalkan pada mereka nilai-nilai kebudayaan. Tim Pengabdian Kepada Masyarakat memberikan contoh bagi anak- anak (role model) bagaimana membaca dengan intonasi yang tepat yaitu dengan metode storytelling. Tim Pengabdian Masyarakat pun berbagi cerita dan pesan moral nilai budaya kepada mereka untuk memberikan manfaat positif setelah membaca buku tersebut.

\section{Storytelling}

Metode storytelling digunakan oleh Tim Pengabdian Kepada Masyarakat untuk meningkatkan minat baca peserta atau anak-anak di TBM Kolong Ciputat. Menurut Tarigan (1981: 35) dengan Storytelling atau bercerita dapat membuat pengertian-pengertian atau makna-makna menjadi jelas. Dengan ini diharapkan pmehaman literasi para anak memiliki peningkatan.

4. Kreatifitas

Situasi Pandemi membuat aktifitas dialihkan langsung dari lokasi TBM Kolong Ciputat ke pembuatan video. Video tersebut dikirimkan kepada para 
anak TBM Kolong Ciputat. Video tersebut diharapkan dapat meningkatkan minat serta kemampuan literasi para anak. Kreatifitas yang berupa Storytelling dengan menggunakan roleplaying boneka diharapkan dapat menyampaikan sebuah cerita daerah berjudul Malin Kundang beserta nilai-nilai budayanya.

\section{Pohon Literasi}

Pohon literasi adalah media yang digunakan untuk memotivasi anak-anak melakukan kegiatam membaca dan menulis. Tim Pengabdian Kepada Masyarakat membuat sebuah gambar pohon yang kemudian di tempel di perpustakaan Taman Baca Masyarakat Kolong. Setiap anak diminta menempelkan daun pada rantingnya. Daun itu berisi kisah cerita tradisional yang dibacakan pada mereka yang mengandung unsur nilai-nilai budaya.

\section{B. Metodologi Penelitian}

Kejadian luar biasa wabah COVID-19 membuat kegiatan PKM pada kali ini dialihkan di rumah masing masing anggota panitia PKM dengan menyiapkan materi dengan sistem daring. Pembuatan materi tersebut ialah melalui sebuah videoyang kemudian dikirimkan ke TBM Kolong Ciputat. Berikut ini tempat, sasaran, dan waktu pelaksanaan kegiatan pengabdian masyarakat adalah sebagai berikut:

1. Tempat Kegiatan: Rumah masing-masing panitia dengan menyiapkan materi dalam bentuk video.

2. Sasaran Kegiatan: Anak-anak TBM Kolong Ciputat

3. Waktu Pelaksanaan Kegiatan: April 2020

Kegiatan kemasyarakatan ini dilakukan di rumah masing-masing panitia dan peserta. Kegiatan yang sebelum ini direncanakan di lokasi TBM Kolong Ciputat dialihkan dengan pembuatan video dari panitia yang ditujukan bagi para peseta atau para anak TBM Kolong Ciputat. Video yang sudah dibuat dikirim kepada TBM Kolong untuk dapat ditonton para anak tersebut dengan tetap mengikuti protokol kesehatan berkaitan dengan wabah COVID19.

Keterbatasan minat anak-anak dalam membaca buku berbahasa Inggris dan minimnya pengenalan mereka pada nilai-nilai yang tersirat dalam sebuah cerita dalam buku adalah permasalahan yang dihadapi di Taman Baca Masyarakat (TBM) Kolong Ciputat. Ini juga adalah adalah hal yang pada umumnya dihadapi ditempat lain. Seperti yang sudah diuraikan sebelumnya, tenaga pengajar dan mahasiswa dari Universitas Pamulang (UNPAM) melakukan metode yang tersampaikan melalui sebuah video untuk mengatasi keterbatasan minat dan pemahaman literasi anak-anak dalam membaca buku cerita dalam bahasa Inggris dan juga menyisipkan pesan nilai- nilai unsur budaya kepada mereka. 


\section{Hasil dan Pembahasan}

Taman Baca Masyarakat atau TBM Kolong, berada di Jalan Dewi Sartika, Ciputat- Tangerang Selatan, didirikan dengan tujuan untuk menambah minat membaca pada anak-anak dan mengisi kegiatan positif untuk mereka. Dengan berusaha menjadi mitra masyarakat sekitar untuk memberikan manfaat bagi anak usia dari tingkat SD (Sekolah Dasar) hingga SMA (Sekolah Menengah Atas) Taman Baca Masyarakat Kolong sering menyelenggarakan kegiatan membaca buku dongeng, kreasi, dan seni. Tempat tersebut gratis dan terbuka untuk umum. Selain itu Taman Baca Masyarakat Kolong pun menyediakan perpustakaan kecil dengan beragam koleksi buku, dan meperslahkan anak-anak atau siapapun yang berkunjung atau singgah dapat membaca buku yang tersedia.

Melihat kesempatan untuk mengabdi kepada masyarakat berdasarkan fakta tersedianya fasilitas seperti Taman Baca Masyarakat Kolong di Ciputat, maka Tim Pengabdian Kepada Masyarakat yang terdiri dari lima orang dosen dan beberapa mahasiswa Universitas Pamulang menginginkan mengisi kegiatan di Taman Baca Masyarakat Kolong Ciputat. Pada awalnya kegiatan direncanakan untuk diadakan di lokasi TBM Ciputat. Karena sebuah kejadian luar biasa yaitu wabah penyakit COVID-19, maka kegiatan dialihkan menjadi pembuatan video yang lalu dapat dinikmati oleh anak-anak TBM Kolong Ciputat. Para panitia melakukan pertemuan secara daring untuk membahas apa-apa saja yang dapat disampaikan di dalam video demi untuk memenuhi tujuan yaitu meningkatkan literasi anak baik itu minat dan pemahaman mereka terhadap buku, terutama buku cerita. Dengan diskusi ini dihasilkan keputusan dari dosen-dosen yang juga mahasiswa untuk memilih buku cerita Malin Kundang.

Salah satu cerita rakyat (selanjutnya disebut mitos) yang ada di dalam masyarakat Sumatera Barat adalah "Malin Kundang". Masyarakat menganggap mitos ini bertema anak durhaka. Alur dari cerita ini adalah mengenai sebuah keluarga yang terdiri atas ibu dan anak yang miskin dan tinggal di sebuah kampung. Untuk memperbaiki kehidupan mereka, si anak yang bernama Malin Kundang pergi merantau. Dirantau, dia sukses dan menikahi seorang gadis. Suatu ketika dia kembali ke kampung halaman-nya. Sang ibu yang mengetahui hal tersebut, langsung menemuinya. Akan tetapi, Malin Kundang merasa malu melihat kondisi ibunya. Dia menolak mengakui ibunya itu di hadapan istrinya. Akibatnya, sang ibu merasa sedih dan juga marah. Dia berdoa kepada Tuhan supaya anaknya itu diberi ganjaran. Angin kencang dan badai turun dan memorakporandakan kapal dan segala yang ada di dalamnya. Malin Kundang menyesal, tetapi sudah terlambat. Dia menjadi batu bersama harta bendanya. Sekarang, batu yang dianggap jelmaan Malin Kundang itu berada di Pantai Airmanis, Padang, Sumatra Barat.

Selanjutnya, didiskusikan bagaimana penyampaian cerita tersebut agar dapat meningkatkan minat keingintahuan anak-anak mengenai isi cerita dan pesan nilai budaya yang terkandung di dalamnya. Di dalam penelitian "NilaiNilai Budaya yang Terkandung dalam Cerita Rakyat Malin Kundang” dapat 
disimpulkan bahwa wujud nilai moral adat istiadat atau budaya yang ditemukan di dalam cerita "Malin Kundang" meliputi: (a) hubungan manusia dengan Tuhan dalam bentuk sikap berdoa dan bersyukur kepada Tuhan; (b) hubungan manusia dengan manusia lain berupa sikap berbakti kepada orangtua, tolong menolong, kasih sayang ibu terhadap anaknya, meminta maaf, dan berterima kasih; dan (c) hubungan manusia dengan dirinya sendiri berupa sadar akan perbuatan salah dan rajin bekerja. Adapun bentuk penyampaian nilai moral yang digunakan, yaitu secara langsung dan tidak langsung.

Para mahasiswa dari Tim Pengabdian Kepada Masyarakat ini memiliki ide untuk menggunakan metode storytelling dan roleplay menggunakan boneka. Untuk langkah lebih lanjutnya, sesama mahasiswa sebagai pelaksana storytelling dan roleplay membuat grup diskusi sendiri untuk mewujudkan rencana tersebut. Para mahasiswa sebagai bagian dari Tim PKM pelaksana melakukan beberapa tahap dalam pembuatan video tersebut, yaitu: 1 . Menyiapkan script, 2. Menyiapkan property (membuat puppet), 3. Perekaman video, 4. Perekaman suara karakter dalam cerita Malin Kundang (dubbing), 5. Mengedit, menggabungkan, dan melengkapi, 6. Revisi adegan, 7. Merekam videopembukaan dan penutupan, 8. Revisi pembukaan, 9. Pembuatan pohon literasi dan video instruksinya, 10. Mengedit pembukaan dari Dosen dan Mahasiswa, 12. Revisi subtitle, dan 13. Tahap akhir penyelesaian video. Dari tahap-tahap tersebut maka hasil akhir video dapat dikirimkan kepada TBM Kolong Ciputat. Tahap-tahap ini dikategorikan sebagai bagian dari kreatifitas dari para panitia yang memberi pengaruh kepada para anak-anak TBM Kolong Ciputat yaitu membangkitkan minat mereka pada cerita Malin Kundang yang disampaikan.

Kemudian, berdasarkan respon yang didapat, fakta yang ditemukan dari analisa kegiatan Pengabdian Kepada Masayarakat ini adalah:

1. Pemilihan Buku yang Tepat

Topik yang dipilih, yaitu cerita rakyat Malin Kundang, adalah tepat. Dapat dinyatakan seperti ini karena para peserta yang adalah peserta anakanak dari TBM Kolong mampu mengikuti dan menyaring informasi dari cerita tersebut berupa nilai budaya yang terkandung di dalamnya, bahwa anak tidak boleh durhaka terhadap orang tuanya. Ini adalah wujud pengingkatan literasi baik dari segi serapan pengetahuan dari sebuah cerita yang sesuai dengan tujuan.

\section{Sharing}

Hasil yang didapat dari kegiatan sharing ini yang adalah bahwa pemberian contoh seperti cara membaca dengan intonasi melalui cara storytelling dengan bermain peran dan juga pembahasan secara menarik tentang pesan nilai budaya kepada peserta dapat dipahami oleh peserta. Pemahaman ini adalah sebagai bukti bahwa kegiatan ini memberikan manfaat positif bagi mereka.

3. Storytelling

Hasil yang didapat setelah Tim Pengabdian Kepada Masyarakat 
menerapkan aktifitas ini adalah berhasil meningkatkan pemahaman literasi dalam mengenal nilai budaya yang ada pada cerita Malin Kundang oleh para peserta atau anak-anak di TBM Kolong Ciputat. Hasil ini sesuai dengan pernyataan Tarigan (1981: 35) bahwa melalui Storytelling atau bercerita dapat dibuat pengertian-pengertian atau makna-makna menjadi jelas.

4. Kreatifitas

Dari kegiatan pengabdian kemasyarakatan ini kreatifitas dihasilkan oleh dua belah pihak, yaitu Tim PKM sendiri dan para peserta. Dari Tim PKM yaitu dengan pembuatan video Storytelling dengan menggunakan roleplaying boneka. Sedangkan dari para peserta yaitu kreatifitas mereka dalam menyimak, menyerap, dan mengambil kesimpulan dari kisah Malin Kundang beserta nilai-nilai budayanya.

\section{Pohon Literasi}

Dalam kegiatan ini, pohon literasi berhasil memotivasi anak-anak melakukan kegiatan membaca dan menulis dengan menjawab pertanyaan yang diambil dari kisah Malin Kundang yang telah mereka simak.

Dari lima hal tersebut, dapat dilihat bahwa metode yang diterapkan oleh Tim Pengabdian Kepada Masyarakat dapat meningkatkan minat ataupun kemampuan lietrasi pada anak-anak TBM Kolong Ciputat.

\section{Penutup} Simpulan

Pelaksanaan kegiatan Pengabdian Kepada Masyarakat yang seharusnya di adakan di Taman Bacaan Masyarakat Kolong Jembatan Ciputat dengan tema meningkatkan minat baca anak-anak terhadap cerita rakyat dan pemahaman nilai budaya di dalamnya pada akhirnya harus dilaksanakan dengan pembuatan video agar dapat diikuti oleh para anak- anak dari rumah. Hal ini guna mengikuti protokol kesehatan terhadap wabah COVID-19. Isi dalam video yang kami buat sebagai panitia adalah penyampaian cerita daerah yaitu Malin Kundang dengan teknik roleplaying dan storytelling. Selain bermain peran, nilai budaya yang terkandung dalam cerita tersebut juga diperkenalkan dalam video secara deskriptif. Hal-hal ini dilakukan untuk membuat anak-anak memiliki minat tidak hanya pada membaca tetapi juga dengan metode lain seperti menyimak berdasarkan metode pendekatan komunikatif. Ini adalah wujud dari usaha dalam peningkatan budaya literasi kepada mereka. Karena budaya literasi yang baik dapat dimulai dengan caracara yang menarik perhatian mereka salah satunya adalah dengan penyampaian cerita melalui roleplay dengan teknik storytelling.

\section{Saran}

Kegiatan ini diharapkan menambah pengetahuan anak-anak terhadap nilai budaya Indonesia yang bisa diterapkan dilingkungan masyarakat. Untuk itu pihak Taman Bacaan Masyarakat (TBM) Ciputat sebaiknya menyediakan beragam buku cerita rakyat dari daerah lain sehingga memperkaya anak-anak akan pentingnya nilai budaya yang bisa diterapkan dalam kehidupan sehari-hari. 


\section{DAFTAR PUSTAKA}

Alwasih, A. (2001). Membangun Kota Berbudaya Literat. Jakarta: Media Indonesia

Harvery, J.G. (2016). The Literacy Mith: Literacy, Education and Demografi. Vienna Yearbook of Population Research Vo. 8, Education and demograph (2010), pp.17-23

Kementerian Pendidikan dan Kebudayaan. (2015). Manual Pendukung Pelaksanaan Gerakan Literasi Sekolah. Direktorat Jenderal Pendidikan Dasar Dan Menengah direktorat Pembinaan Sekolah Menengah Pertama. Jakarta: Kemendikbud.

Sarumpaet, A, dkk. (1992). Permainan Besar. Jakarta: Dirjen Dikti Proyek Pembinaan Tenaga Kependudukan.

Sudarmi. (2018). "Peran Manajemen Pengelolaan Pendidikan Pada Gerakan Literasi Di Sekolah”. Jurnal Akademika. Vol. 14. NO. 1 Juni 2018.

Sulham, H. (2006). Pengembangan Karakter Pada Anak Didik: Manajemen Pembelajaran Guru Menuju Sekolah Yang Efektif.. Surabaya: Intelektual. Hamidi

Suragangga, I Made Ngurah. (2017). "Mendidik Lewat Literasi Untuk Pendidikan Berkualitas". Jurnal Penjaminan Mutu INSTITUT HINDU DHARMA NEGERI. Vol. 3 No. 2 Agustus 2017. (http://ejournal.ihdn.ac.id/index.php/JPM).

Tarigan, Henri Guntur. (1981). Berbicara: Sebagai Suatu Keterampilan Berbahasa. Bandung: Angkasa. 